\title{
An Expeditious Approach to the Synthesis of Novel Quinolino and Diazacino Condensed Analogues of Azepino [3, 2-b] Carbazole-2-one of Medicinal Interest
}

\author{
Meenakshi Agrawal ${ }^{1}$, Jaya Dwivedi ${ }^{1, *}$, Dharma Kishore ${ }^{1}$, Sonika Jain ${ }^{1}$, Achal Mishra $^{3}$, \\ Smita Jain ${ }^{2}$ and Swapnil Sharma ${ }^{2}$
}

${ }^{1}$ Department of Chemistry, Banasthali Vidyapith, Banasthali, Rajasthan, INDIA. ${ }^{2}$ Department of Pharmacy, Banasthali Vidyapith, Banasthali, Rajasthan, INDIA.

${ }^{3}$ Shri Shankaracharya Technical Campus, Bhilai, Chhattisgarh, INDIA.

\begin{abstract}
Background: Quinolino and diazacino are important heterocyclics moiety, which have been reported to possess various activities such as antiallergenic, antifungal, hypocholesterolemic, antibacterial and antiviral activities. The activities of these compounds were related to inhibition of bacterial dehydrogenase enzyme which is one of the important targets studied for designing of antimicrobial drugs. Further, molecular docking approached is used in the present study for confirming potent molecules. Objectives: Aim of the study is to synthesize a series of quinolino and diazacino condensed analogues and evaluation of their anti-microbial activity. Methods: Quinolino and diazacino condensed analogues of azepino [3, 2-b] carbazole-2-one were synthesized by Friedel-Craft acylation and Pfitzinger reaction. Structures of synthesized compounds were characterized by FTIR and HNMR and were evaluated for antimicrobial activity by in-vitro bacterial dehydrogenase activity agar well diffusion assay. Further, in order to determine the binding affinity, molecular docking of synthesized compounds was also performed using bacterial (3NUH of $E$. colli) and fungal proteins (1FI4). In addition, bacterial dehydrogenase inhibitory activity of most active compound was performed using MTT assay. Results: Synthesized compounds $(3,4$ and 6$)$ caused impressive antibacterial and antifungal activities in-vitro assay when compared to the ciprofloxacin and fluconazole. And molecular docking studies also revealed that the synthesized compounds 3,4 and 6 exhibits good to excellent affinity towards target microbial proteins. Conclusion: Synthesized compounds $(3,4$ and 6$)$ hold substantial antibacterial potential and require further exploration to establish them as therapeutic candidates in clinical management. Key words: Antimicrobial, Azepino [3, 2-b] carbazole-2-one, Pfitzinger reaction, Beckmann rearrangement, Organocatalyst.
\end{abstract}

\section{INTRODUCTION}

Carbazoles exhibits a variety of biological activities and because of this, their derivative form an attractive target in synthesis. ${ }^{1}$ The proven record of impressive pharmaceutical properties shown by carbazole derivative is attributed to the planarity of its molecular framework. It is this structural feature of carbazoles that confers it the ability to undergo intercalation with DNA chain. This property is of paramount importance in manifestations of its mutagenic or anti- neoplastic behaviour. ${ }^{2}$ Unlike to many other organic compounds, the carbazoles have an unique feature to act as building blocks for electroluminescent materials and light emitting diodes. ${ }^{3,4}$ Owing to their innate ability and inherent potentials, they have remained in the mainstay on the chemical scene, as evergreen agents in the discovery of novel drugs. Recently, two carbazole analogues a pyridozepine-9-bromo derivative, (1) $)^{5}$ and azpaullone (9-cyano-
Submission Date: 31-12-2020; Revision Date: 17-09-2021; Accepted Date: 09-11-2021.

DOI: 10.5530/ijper.56.1s.47 Correspondence: Dr. Jaya Dwivedi Department of Chemistry, Banasthali Vidyapith, Banasthali-304022, Rajasthan, INDIA. E-mail: jayadwivedi@yahoo. co.in

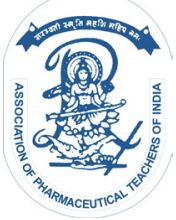

www.ijper.org 
1-aza paullone (2) $)^{6}$ have been reported to exhibit impressive activity in promoting $\beta$-cell protection and replication. A further study on enzymatic assays on these revealed that some 1-azapaullones showed selective GSK-3 inhibitory properties and promoted INS-1E $\beta$-cell against glucolipotoxicity induced cell death. It also stimulated the regulator of $\beta$-cell growth and development through the mRNA expression of the $\beta$-cell transcription factor Pax 4.

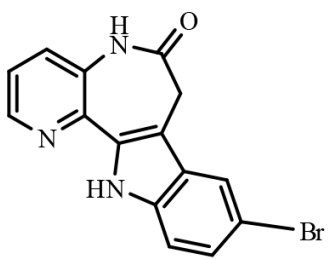

(1)

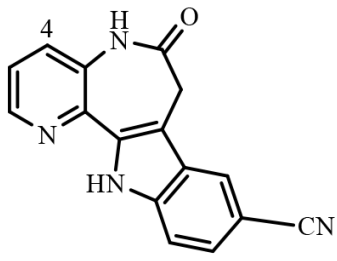

(2)
A survey of literature on carbazole and quinoline derivatives revealed that a quinoline-4-carboxylic acid derivative viz, (2'-nitrophenyl)-3-methyl-5,6,13trihydro carbazole [1,2-b] quinoline-7-carboxy-1sulfone(3) wherein a carbazole nucleus is fused to quinoline ring showed significant antimicrobial activity. ${ }^{7}$ Quinoline nucleus occurs abundantly in many synthetic materials. ${ }^{8}$ Many of these have been known to exhibit antiviral, ${ }^{9}$ anti-fungal, ${ }^{10}$ antibacterial, ${ }^{11}$ Antiallergenic, ${ }^{12}$ hypocholesterolemia ${ }^{13}$ and hypovolemic ${ }^{14}$ etc. activities. Besides this thieno and benzothieno quinolines show remarkable antifungal, antibacterial and anti-tumour activities. ${ }^{15}$ It has been reported that quinoline molecular framework embellished with styryl motif show HIV integrase inhibitor activity. ${ }^{16}$

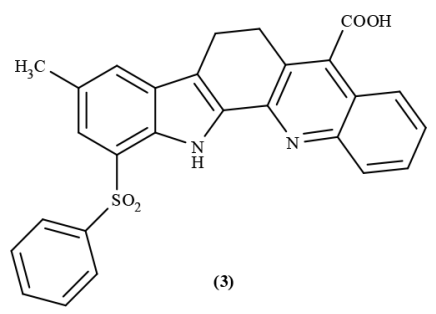

It is evident from the literature that heterocyclics that contain quinolones, ${ }^{17}$ carbazoles, ${ }^{18}$ azepinones ${ }^{19}$ etc. in their molecules exhibit a wide variety of biological activities such as, anti-mycobacterial, ${ }^{20}$ anti-leishmanicidal, ${ }^{21}$ antitumor, ${ }^{22}$ anti-proliferative ${ }^{23}$ and anti-leukemic ${ }^{24}$ etc. With a view to explore their pharmaceutical potential further, it occurred to as mind to undertake the synthesis of some such molecules which incorporated (a) quinoline-4-carboxylic acid and azepinone framework (b) diazocene pharmacophores on to the carbazole nucleus. In scheme- 2 where the synthesis of these compounds have been shown, one can easily decern in compound 4 the presence of carbazole nucleus on one side of the azepinone nucleus and quinoline-4-carboxylic acid on its other side. In compound 6 one can see the presence of eight membered diazocene nucleus attached to the carbazole ring. This concept of synthesis emerged on this premise that the presence of these pharmacophores in tandem as a part of the same molecule could bring a favorable impact on the overall biological activity of carbazole nucleus. We report in this communication that the application of Pfitzinger reaction on 3 and Beckmann rearrangement on 5 provided a very convenient synthetic entry to 4 and 6 respectively.

Synthetic strategy given in Scheme 1 and 2 was followed to afford the target compounds.

\section{Experimental}

Open capillary tube method was employed to record the melting point of the compounds. IR, and ${ }^{1} \mathrm{HNMR}$ spectra (in $\mathrm{CDCl}_{3}$ expressed in $\delta \mathrm{ppm}$ with tetramethylsilane (TMS) as internal reference) were recorded respectively,

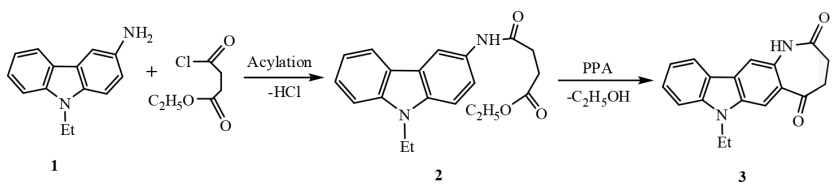

Scheme 1
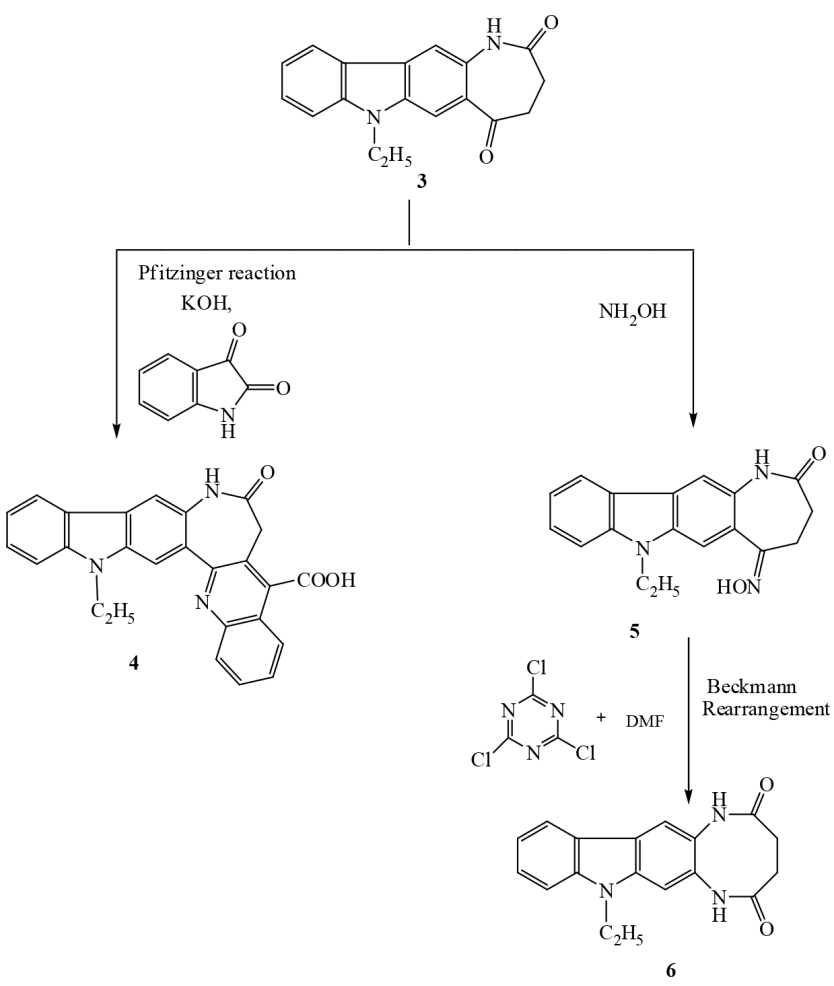

Scheme 2 
on Schimadzu FTIR 8400S and Bruker DRX-400 MHz spectrometer.

\section{Synthesis of ethyl 4-(9-ethyl-9H-carbazol-3- ylamino)-4-oxobutanoate (2)}

Ethyl succinyl chloride (0.01 mole) and 3-Amino-9ethyl carbazole (1) (0.01 mole) were mixed in $5 \mathrm{ml}$ dry pyridine and refluxed for $15 \mathrm{~min}$. Resulting mixture was transferred in $200 \mathrm{ml}$ ice cold water with constant stirring. The settled solid was filtered, washed with cold water. Further, the target compound 2 (yield 83\%, m.p. $89-90^{\circ} \mathrm{C}$ ) was achieved after recrystallization from hot water containing a few drops of methanol.

\section{Synthesis of 7-ethyl-3, 4 dihydroazepino [3,2-b] carbazol-2,5 (1H,7H)-dione (3)}

A mixture of ethyl 4-(9-ethyl-9H-carbazol-3-ylamino)-4oxobutanoate (2) (0.006 mole) and PPA ( $5 \mathrm{ml})$ was heated at $150^{\circ} \mathrm{C}$ for $4 \mathrm{~h}$ with intermittent TLC monitoring. The $\mathrm{pH}$ of resulting mixture was increased by adding a concentrated $\mathrm{Na}_{2} \mathrm{CO}_{3}$ solution after cooling it up to $20^{\circ} \mathrm{C}$. The compound was extracted with ethyl acetate and dried over anhydrous $\mathrm{Na}_{2} \mathrm{SO}_{4}$ and concentrated in vacuo. The residue thus obtained was purified by column chromatography on silica gel with $\mathrm{CHCl}_{3}$ as an eluent to give 3 (yield $60 \%$, m.p. $158-160^{\circ} \mathrm{C}$ ). IR $(\mathrm{KBr}) \mathrm{cm}^{-1}$ 3342[NH str.], 2945[C-H str.ArH], 1702 [C=O str.], $1713[\mathrm{C}=\mathrm{O}], 1454\left[\mathrm{C}-\mathrm{H}\right.$ str. $\left.\mathrm{CH}_{3}\right], 1070[\mathrm{C}-\mathrm{N}$ str.]. ${ }^{1} \mathrm{H}-\mathrm{NMR}\left(\mathrm{CDCl}_{3}\right) \delta, 8.0(1 \mathrm{H}, \mathrm{s}, \mathrm{NH}), 7.77(1 \mathrm{H}, \mathrm{s}, \mathrm{CH})$, $7.64(1 \mathrm{H}, \mathrm{s}, \mathrm{CH}), \quad 7.56(1 \mathrm{H}, \mathrm{d}, \mathrm{CH}), \quad 7.42(1 \mathrm{H}, \mathrm{d}, \mathrm{CH})$, $7.06(1 \mathrm{H}, \mathrm{t}, \mathrm{CH}), \quad 7.04(1 \mathrm{H}, \mathrm{t}, \mathrm{CH}), \quad 3.99\left(2 \mathrm{H}, \mathrm{q}, \mathrm{CH}_{2}\right)$, $2.90\left(2 \mathrm{H}, \mathrm{t}, \mathrm{CH}_{2}\right), 2.45\left(2 \mathrm{H}, \mathrm{t}, \mathrm{CH}_{2}\right), 1.50\left(3 \mathrm{H}, \mathrm{t}, \mathrm{CH}_{3}\right)$. MS: $[\mathrm{m} / \mathrm{z}] 293$ (19\%); Anal. Calcd./ found for $\mathrm{C}_{18} \mathrm{H}_{16} \mathrm{~N}_{2} \mathrm{O}_{2}$ : C, 73.99/73.63; H, 5.56/5.57; N, 9.55/ 9.14

\section{Synthesis of 2-oxo-4, 6-dihydro-N-ethyl-carbazolo- 1H-azepino[4,5-b]quinoline-11-carboxylic acid (4)}

Equimolarquantities of 7-ethyl-3,4dihydroazepino[3,2-b] carbazol-2,5 $(1 \mathrm{H}, 7 \mathrm{H})$-dione (3) and isatin was mixed in $50 \%$ aq. EtOH containing $\mathrm{KOH}(3 \mathrm{~g})$ and heated under reflux for $20 \mathrm{~h}$. Further, the mixture was diluted with 50\% aq. EtOH to obtain a homogenous mixture and acidified with $\mathrm{AcOH}$. The precipitate was collected, washed with $30 \%$ aq. $\mathrm{EtOH}$ and recystallized from $\mathrm{MeOH}$ to give 4, (yield 62\%, m.p. 295-296 ${ }^{\circ} \mathrm{C}$ ). IR (KBr) $\mathrm{cm}^{-1}$ 3474[OH str.], 3312[NH str.], 2853[C-H str. ArH], 1784 [C $=\mathrm{O}$ str.], $1718[\mathrm{C}=\mathrm{O}$ str.], $1624[\mathrm{C}=\mathrm{C}$ str. $\mathrm{ArH}$ ], $1480\left[\mathrm{C}=\mathrm{N}\right.$ str.], $1078\left[\mathrm{C}-\mathrm{N}\right.$ str.], ${ }^{1} \mathrm{H}-\mathrm{NMR}\left(\mathrm{CDCl}_{3}\right) \delta$ 10.8(1H, s, OH), $9.00(1 \mathrm{H}, \mathrm{d}, \mathrm{CH}), 8.32(1 \mathrm{H}, \mathrm{s}, \mathrm{CH})$. $7.78(1 \mathrm{H}, \mathrm{t}, \mathrm{CH}), 7.74(1 \mathrm{H}, \mathrm{t}, \mathrm{CH}), 7.60(1 \mathrm{H}, \mathrm{s}, \mathrm{CH})$, $7.55(1 \mathrm{H}, \mathrm{d}, \mathrm{CH}), \quad 7.41(1 \mathrm{H}, \mathrm{d}, \mathrm{CH}), \quad 7.10(1 \mathrm{H}, \mathrm{t}, \mathrm{CH})$, $7.00(1 \mathrm{H}, \mathrm{t}, \mathrm{CH}), \quad 3.99\left(2 \mathrm{H}, \mathrm{q}, \mathrm{CH}_{2}\right), \quad 3.42\left(2 \mathrm{H}, \mathrm{s}, \mathrm{CH}_{2}\right)$,
1.54(3H,t, $\left.\mathrm{CH}_{3}\right) ; \mathrm{MS}:[\mathrm{m} / \mathrm{z}] 421$ (20\%); Anal. Calcd./ found for $\mathrm{C}_{26} \mathrm{H}_{19} \mathrm{~N}_{3} \mathrm{O}$ : C, 74.14/ 74.35; $\mathrm{H}, 4.58 /$ $4.51 ; \mathrm{N}, 9.97 / 9.52$.

\section{Synthesis of 8-ethyl-5-(hydroxyimino)-4, 5-dihydro- 1H-azocino [3, 2-b] carbazol-2,6-(3H,8H)-dione (5)}

In a round bottom flask $(500 \mathrm{ml})$ hydroxylamine hydrochloride (20mmol), 7-ethyl-3, 4 dihydroazepino [3,2-b] carbazol-2,5 (1H,7H)-dione (3) $(10 \mathrm{mmol}), 50 \mathrm{ml}$ of rectified spirit and $10 \mathrm{ml}$ of water were taken. Solid sodium hydroxide (pellet form) (2.8 g) was added slowly with continuous stirring the to avoid vigorous reaction the flask was cooled in running tap water. The mixture was refluxed for $30 \mathrm{~min}$ when all the sodium hydroxide pellets were dissolved. The contents of the flask were cooled and poured into a concentrated $\mathrm{HCl}(7 \%)$. The desired product 5 (yield $67 \%$, m.p. $180-182^{\circ} \mathrm{C}$ ) was obtained after filtration followed by washing and recrystallization from methanol. IR $(\mathrm{KBr}) \mathrm{cm}^{-1}$ 3340[NH str.], 2925[C-H str.ArH], 1780-1707[C=O str.], 1639[C=C str. $\mathrm{ArH}$ ], 1432 [C=N str.], 814 [mono-sub]. ${ }^{1} \mathrm{H}-\mathrm{NMR}\left(\mathrm{CDCl}_{3}\right) \delta 11.11(1 \mathrm{H}, \mathrm{s}, \mathrm{OH}), 8.19(2 \mathrm{H}, \mathrm{s}, \mathrm{CH})$, $8.3(1 \mathrm{H}, \mathrm{s}, \mathrm{NH}), 7.7(1 \mathrm{H}, \mathrm{d}, \mathrm{CH}), 7.9(1 \mathrm{H}, \mathrm{s}, \mathrm{CH}), 7.51$ $(1 \mathrm{H}, \mathrm{d}, \mathrm{CH}), 7.35 \quad(2 \mathrm{H}, \mathrm{t}, \mathrm{CH}), \quad 3.79 \quad\left(2 \mathrm{H}, \mathrm{q}, \mathrm{CH}_{2}\right), \quad 3.16$ $\left(2 \mathrm{H}, \mathrm{t}, \mathrm{CH}_{2}\right), 2.42\left(2 \mathrm{H}, \mathrm{t}, \mathrm{CH}_{2}\right), 1.27\left(3 \mathrm{H}, \mathrm{t}, \mathrm{CH}_{3}\right) . \mathrm{MS}$ : [m/z] 301 (25\%); Anal. Calcd./found for $\mathrm{C}_{18} \mathrm{H}_{17} \mathrm{~N}_{3} \mathrm{O}_{2}$ : C, 70.34/ 70.72; H, 5.58/ 5.54; N, 13.67/ 13.96.

\section{Preparation of 8-ethyl-3, 4-dihydro-1H-[1, 4] diazocino[2,3-b]carbazole-2,5(6H,8H)-dione (6)}

2, 4, 6-Trichloro-1, 3, 5 triazine (TCT) $(1.84 \mathrm{~g}, 10.0 \mathrm{mmol})$ was added to DMF $(2 \mathrm{ml})$, maintained at $25^{\circ} \mathrm{C}$. After the formation of white solid, the reaction was monitored (TLC) until to the complete disappearance of TCT. Then, 8-ethyl-5-(hydroxyimino)-4, 5-dihydro-1H-azocino [3, 2-b] carbazole-2, 6(3H, 8H)-dione (5) (3.35g, $10 \mathrm{mmol})$ in DMF $(15 \mathrm{ml})$ was added. The mixture was stirred at room temperature, monitored (TLC) until the completion of reaction $(20 \mathrm{~h})$. Water $(20 \mathrm{ml})$ was added, the solid obtained was washed with $15 \mathrm{ml}$ of a saturated solution of $\mathrm{Na}_{2} \mathrm{CO}_{3}$, followed by $1 \mathrm{~N} \mathrm{HCl}$ and brine. It was then dried over anhydrous sodium sulphate and the solvent was evaporated to give 6,2.70g (yield 87\%), m.p. $155-157^{\circ} \mathrm{C}$ IR $(\mathrm{KBr}) \mathrm{cm}^{-1} 3354$ [NH str.], 2937 [C-H str. $\mathrm{ArH}], 1778-1705[\mathrm{C}=\mathrm{O}$ str.], $1631[\mathrm{C}=\mathrm{C}$ str. $\mathrm{ArH}$, $1420\left[\mathrm{C}=\mathrm{N}\right.$ str.], 810 [mono-sub]. ${ }^{1} \mathrm{H}-\mathrm{NMR}\left(\mathrm{CDCl}_{3}\right)$ $\delta \quad 9.0(2 \mathrm{H}, \mathrm{s}, \mathrm{NH}), \quad 7.45(1 \mathrm{H}, \mathrm{d}, \mathrm{CH}), \quad 7.36(2 \mathrm{H}, \mathrm{s}, \mathrm{CH})$, $7.39(1 \mathrm{H}, \mathrm{d}, \mathrm{CH}), \quad 7.06(1 \mathrm{H}, \mathrm{t}, \mathrm{CH}), \quad 7.03(1 \mathrm{H}, \mathrm{t}, \mathrm{CH}), \quad 3.87$ $\left(2 \mathrm{H}, \mathrm{q}, \mathrm{CH}_{2}\right), 2.56\left(4 \mathrm{H}, \mathrm{s}, \mathrm{CH}_{2}\right), 1.49\left(3 \mathrm{H}, \mathrm{t}, \mathrm{CH}_{3}\right) . \mathrm{MS}$ : $[\mathrm{m} / \mathrm{z}] 307\left(25 \%\right.$,); Anal. Calcd. / found for $\mathrm{C}_{18} \mathrm{H}_{17} \mathrm{~N}_{3} \mathrm{O}_{2}$ : C, 70.34/ 70.72; H, 5.58/ 5.54; N, 13.67/ 13.96. 


\section{Molecular docking}

Docking of the desired heterocyclic scaffolds 3, 4 and 6 obtained from scheme- 1 and 2 was carried out to determine the binding ability of the active materials in binding area of the bacterial and fungal proteins. The target proteins were retrieved from the protein databank PDB ID for bacterial protein is $3 \mathrm{NUH}$ of E. coli and for fungal protein 1FI4 as Mevalonate 5-diphosphate decarboxylase was used. The solvent molecules were removed, hydrogen was added and saved as pdb for further docking. To get a stable conformation of the protein molecule the $2 \mathrm{D}$ structure of the compounds were converted in 3D structure with energy minimization and saved as pdb file. All the docking studies were done by using Arguslab, ${ }^{25}$ after completion of the docking, $2 \mathrm{D}$ pose was determined by discovery studio visualizer. ${ }^{26}$ In the present study ciprofloxacin and fluconazole was used as standard for bacterial and fungal studies respectively.

\section{In-vitro bacterial dehydrogenase activity}

Bacterial dehydrogenase inhibitory testing of synthetic compounds (3, 4 and 6) was performed using [3(4,5-dimethylthiazol-2-yl) -2,5-diphenyltetrazolium bromide] tetrazolium (MTT) for experimental reduction by specific modifications. ${ }^{27}$

Briefly, a $200 \mu \mathrm{L}$ bacterial culture (prepared at 0.5 McFarland turbidity standard, approx. $10^{8} \mathrm{CFU} / \mathrm{ml}$ ) was inoculated in $10 \mathrm{ml}$ YEMB medium and incubated at $37^{\circ} \mathrm{C}$ for $12 \mathrm{hr} .1 \mathrm{ml}$ bacterial cells were harvested at 12,000 $\mathrm{rpm}$ for 2-3 min and washed twice with PBS buffer ( $\mathrm{pH} 7.0)$ and resuspended with the same buffer followed by addition of $0.1 \mathrm{mg} / \mathrm{ml}$ MTT. The sample was incubated for $6 \mathrm{~h}$ in dark at $37^{\circ} \mathrm{C}$. Further, samples were withdrawn at various incubation periods and subsequently $30 \mu \mathrm{l}$ formaldehyde was added to extinguish the reaction. Finally, the absorbance was recorded at $570 \mathrm{~nm}$ using a UV-Vis spectrophotometer (Labindia, India).

\section{RESULTS AND DISCUSSION}

For making our synthetic protocol depicted in scheme-2 to succeed to furnish 4, 5 and 6 , a suitable strategy for the formation of the intermediate 3 was required. As shown in scheme-1, the synthesis of 3 was achieved in two steps from 9-ethyl-3-amino carbazole (1). 1 underwent a smooth interaction with ethyl succinoyl chloride to give the ester 2. Cyclocondensation of 2 under the conditions of Friedel-Craft-acylation with PPA afforded 3 in good yield.

Molecules containing a $\mathrm{COCH}_{2}$ group are prone to undergo reaction with isatin in strongly alkaline medium.
This reaction offers an easy convenient entry to quinoline-4-carboxylic acids. ${ }^{28}$ This strategy was applied on 3 to form 4 in moderate to good yield.

Diazocene derivative 6 was realized through a very mild Beckmann rearrangement of the ketoxime 5 with an organo catalyst derived from TCT + DMF. In usual practice a strong acid was employed to catalyze the rearrangement of ketoximes. ${ }^{29} \mathrm{~A}$ search for an alternate mild reagent for this rearrangement suggested the use of the above organocatalyst. ${ }^{30,31}$ In this method, the ketoxime interacted with the product formed from DMF + TCT (2, 4, 6 trichloro-1, 3, 5-triazine) to give the amide (Scheme 4). The rearrangement with this reagent was carried out with 1 mol. equiv. of ketoxime in DMF. Treatment of ketoxime 5 under these conditions formed the diazocene derivatives 6 in an excellent yield.

The formation of the products 4 from 3 and 6 from 5 have been rationalized through the mechanistic pathways portrayed in schemes 3 and 4 respectively.

The authenticity of the products 3,4 and 6 were corroborated from their physical data viz; (microanalytical, IR, ${ }^{1} \mathrm{HNMR}$ and MS spectral data).

\section{Antibacterial and antifungal activity}

7-Ethyl-3,4 dihydroazepino[3,2-b] carbazole-2,5 $(1 \mathrm{H}, 7 \mathrm{H})$-dione (3), quinoline-4-carboxylic acid derivative (4) and diazocino derivative (6) were screened for their in-vitro antibacterial and antifungal activities using bacterial species (B. substilis, E. coli, and P. aeruginosa) and fungal species (F. oxysporum, M. phaseolina, and A. flavus) employing disc-diffusion method. $\mathrm{CHCl}_{3}$ was used

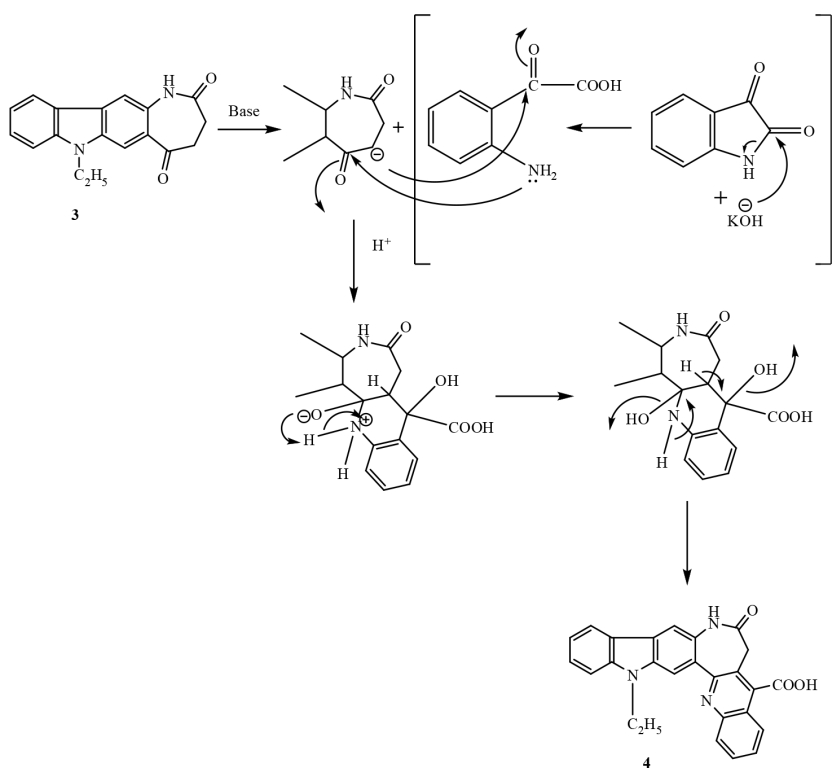

Scheme 3: Formation of 4 from 3 by Pfitzinger Reaction. 


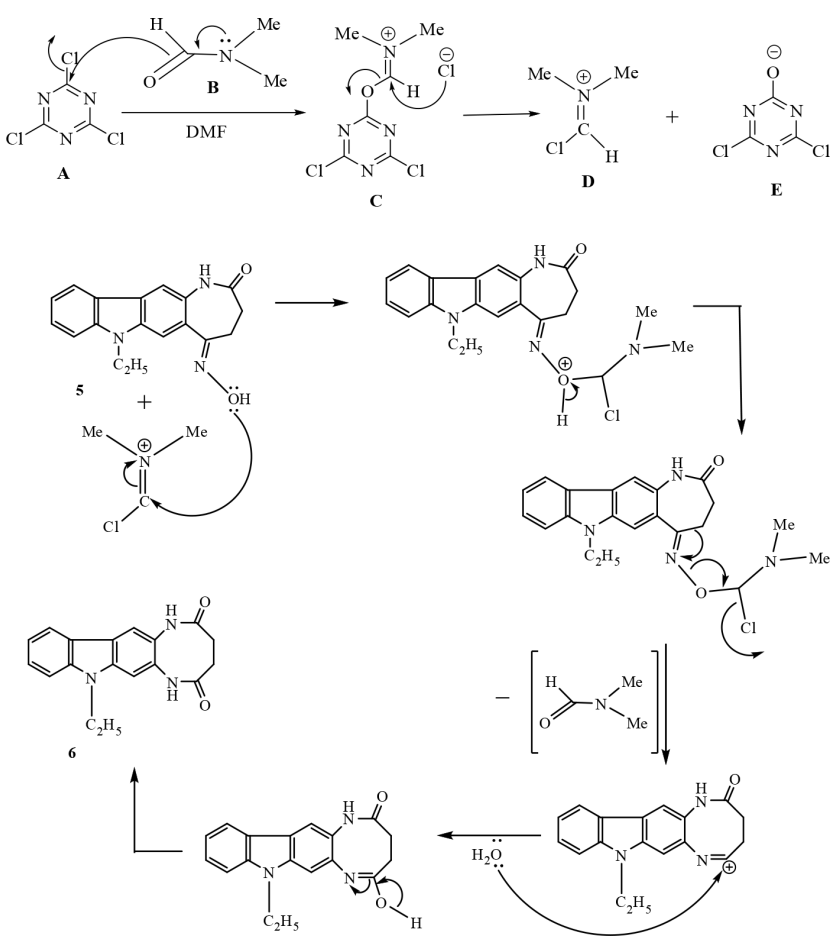

Scheme 4: Formation of 6 from the oxime 5 by Beckmann rearrangement using TCT+DMF.

as solvent for preparation of the stock solutions and further dilutions.

Compound (s) 3, 4 and 6 was examined in vitro for antibacterial potential against three different bacterial strains viz. B. subtilis, E. coli, and P. aeruginosa. Zone of inhibition for each compound were determined and compared with ciprofloxacin. All the three compounds were found active and exhibited impressive inhibition of targeted strains. At $400 \mu \mathrm{g} / \mathrm{ml}$, compound 4 and 6 caused maximum inhibition of $E$. coli whereas compound 3 exhibited maximum inhibition of $B$. subtilis. The compound 6 showed only moderate activity (Table 1).

Similarly, in antifungal study, all the three compounds 3, 4, 6 caused impressive inhibition of targeted fungal strains. In particular, compound $4(400 \mu \mathrm{g} / \mathrm{ml})$ showed maximum inhibition of $A$. flavus followed by compound 6. Compound $3(400 \mu \mathrm{g} / \mathrm{ml})$ exhibited highest inhibitory activity against $M$. phaseolina.

\section{Molecular docking}

The affinity of compounds was presented by docking score (binding energy in $\mathrm{kcal} / \mathrm{mol}$ ), more the negative value suggests the better binding affinity. The standard ligand Ciprofloxacin and Fluconazole have docked efficiently with very good docking score $-7.58 \mathrm{kcal} /$ $\mathrm{mol}$ and $-8.41 \mathrm{kcal} / \mathrm{mol}$ (Table 2 and 3 ) with the target proteins (PDB Id-3NUH and 1FI4). The nitrogen and oxygen atoms of the selected compound were available

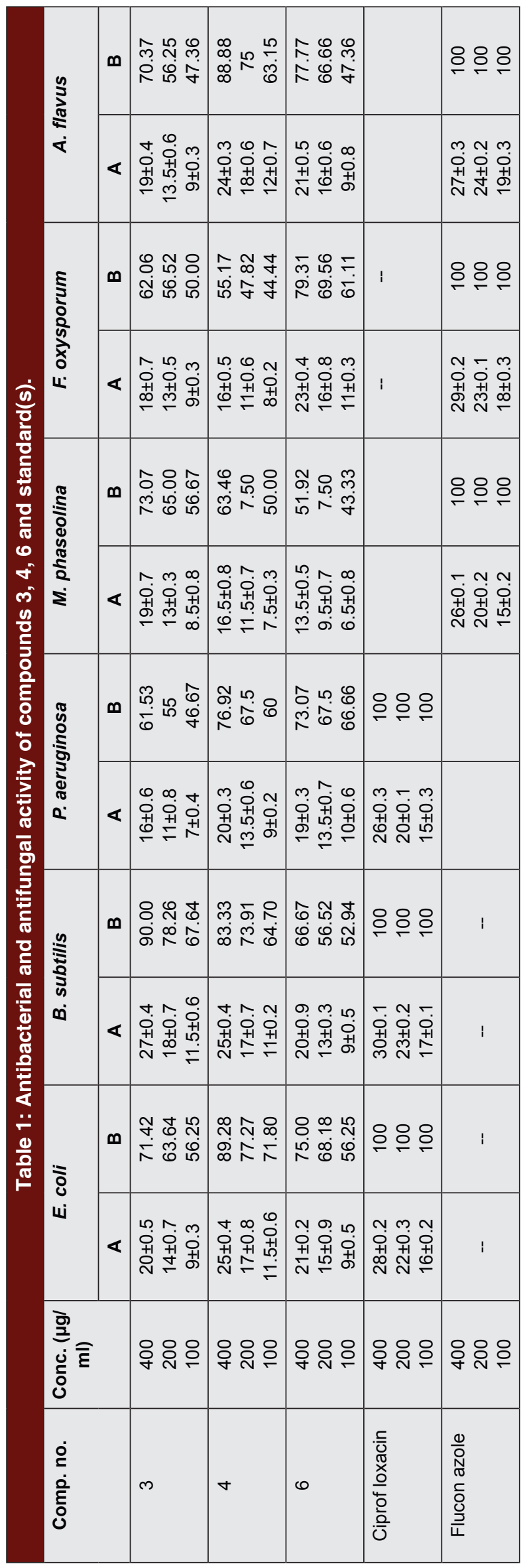




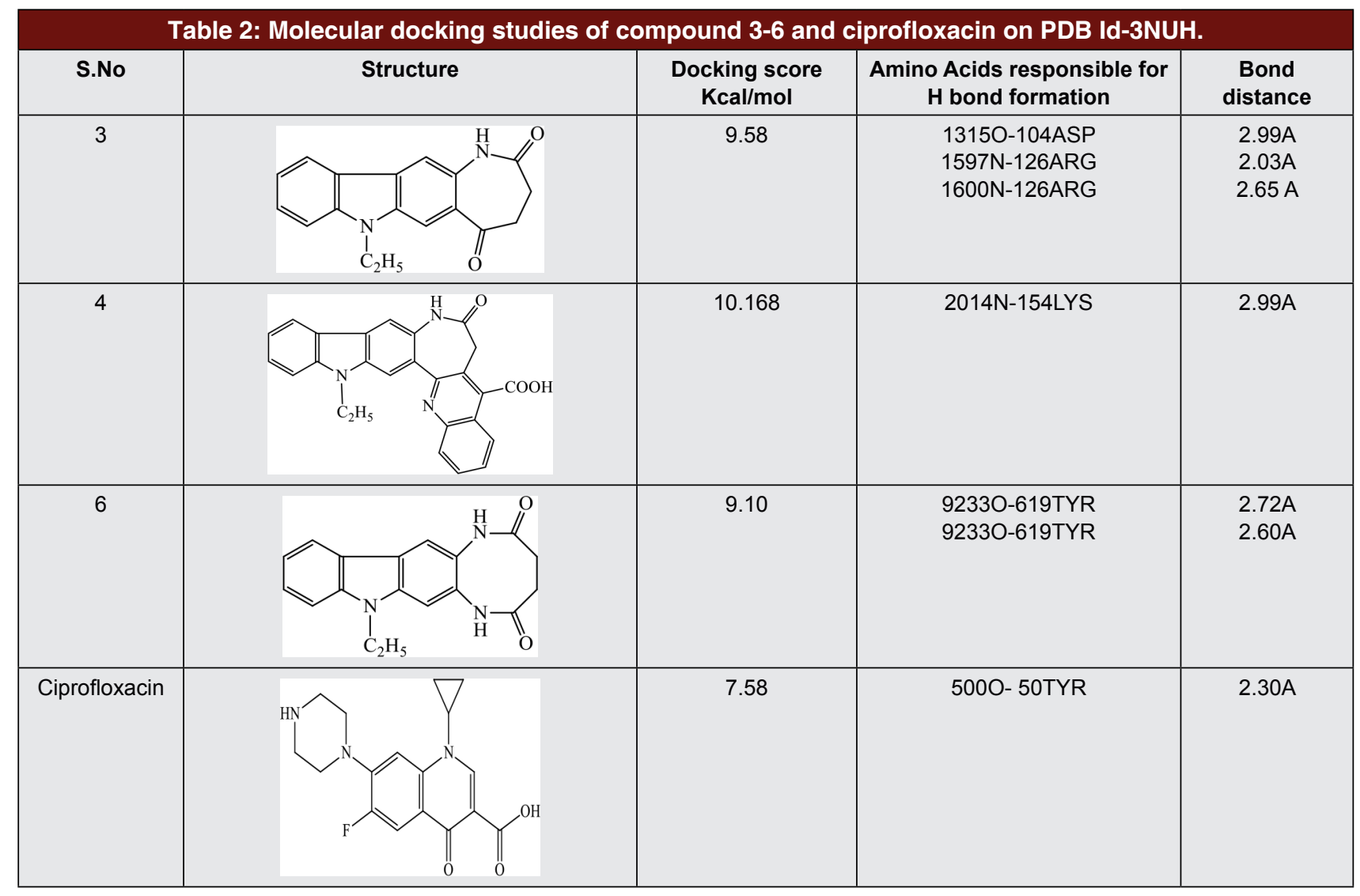

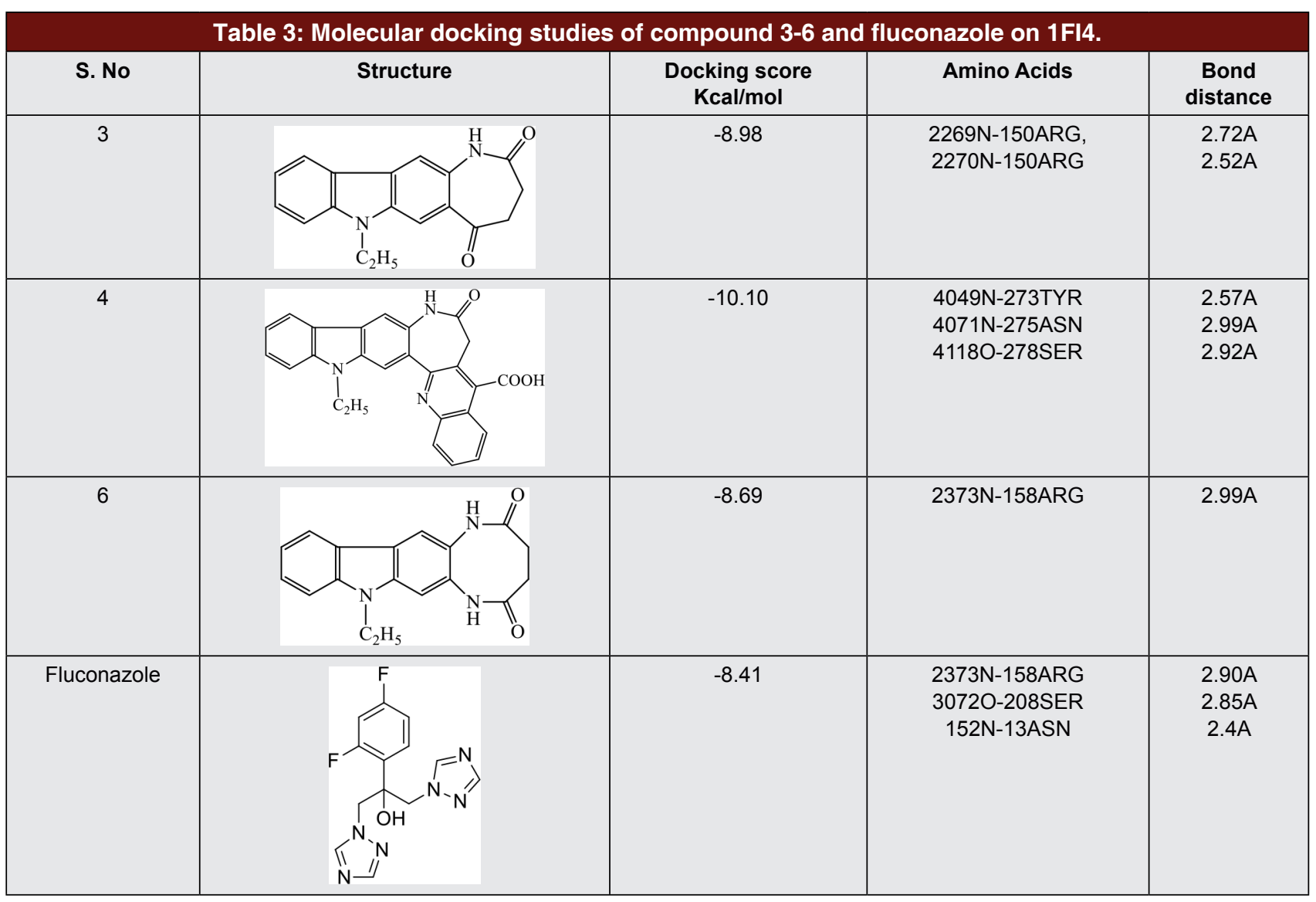


for the hydrogen bond formation with the different amino acids of the target protein. When the docking of synthesized compounds was performed on the selected proteins the docking score for compounds were shown the greater binding affinity as compare to ciprofloxacin (Table 2 and 3) particularly compound 4 (10.168kcal/ mol) has the very good score. In the second docking study for anti- fungal activity all the compounds were comparable to the standard fluconazole and again compound no 4 has the highest docking score $(-10.10$ $\mathrm{kcal} / \mathrm{mol})$. Study of docking was also suggested that amino acid residues 104ASP, 126ARG, 154LYS, 619TYR, 619TYR, 126ARG, 50TYR were participates in the different bond formation like hydrogen bond, Pi-anion interaction, Pi-sigma interaction, alkyl and Pi-alkyl interactions for target protein and 158ARG, 119ALA, 155SER, 302ASP, 260PHE and 279PHS, 265LEU, 272PHE, 273TYR, 278SER are the amino acid residues play a key role for bond formation in fungal activity of the selected protein target (Figure 1-4).

\section{In-vitro bacterial dehydrogenase activity}

The ability of compounds (3,4 and 6) to inhibit bacterial dehydrogenase was tested using the MTT trial. $^{32}$ Compounds has created a time-dependent
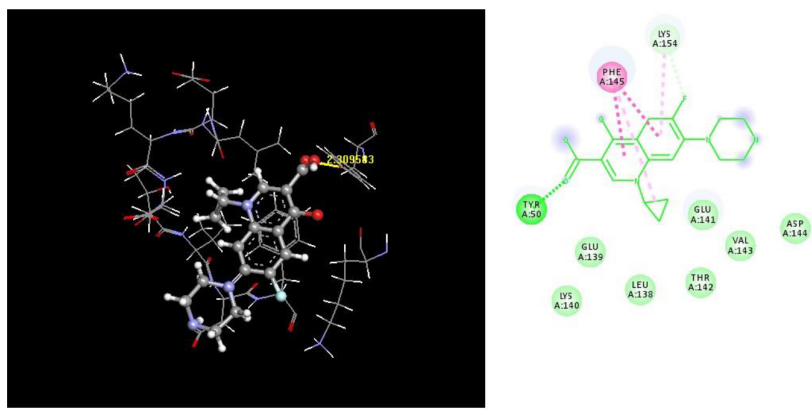

Figure 1: 3D and 2D pose view of the ciprofloxacin showing different bonds including hydrogen bonds and bond distance with different amino acid residues.
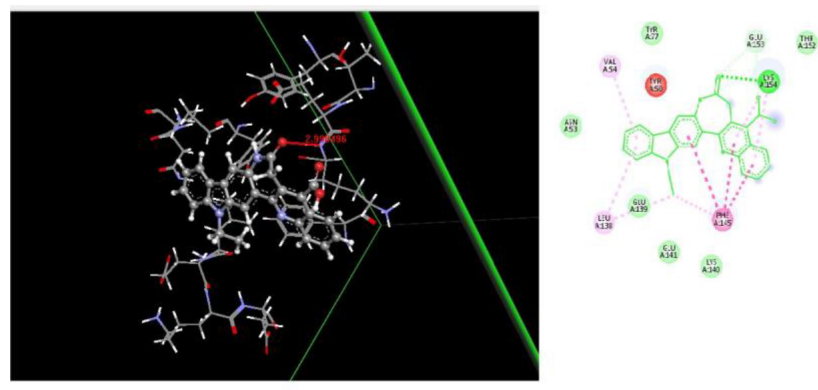

Figure 2: 3D and 2D pose view of the compound 4 showing different bonds including hydrogen bonds and bond distance with active amino acid residues.
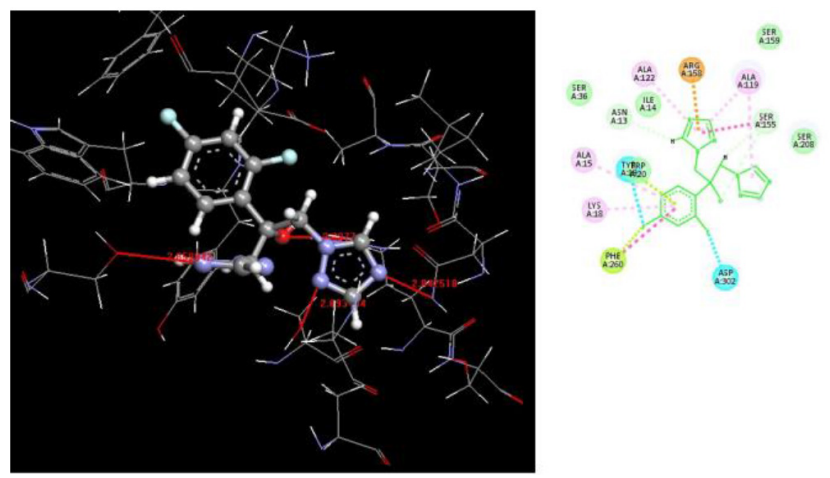

Figure 3: 3D and 2D pose view of the Fluconazole showing different bonds including hydrogen bonds and bond distance with different amino acid residues.
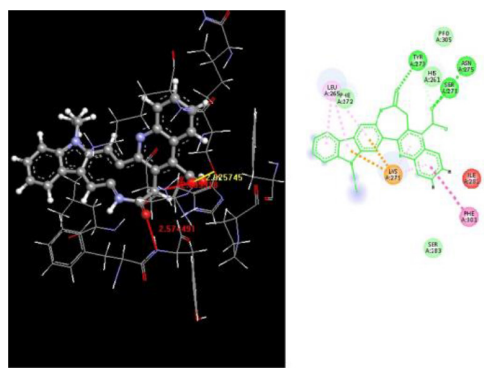

Figure 4: 3D and 2D pose view of the best active compound 4 showing different bonds including hydrogen bonds and bond distance with different amino acid residues.

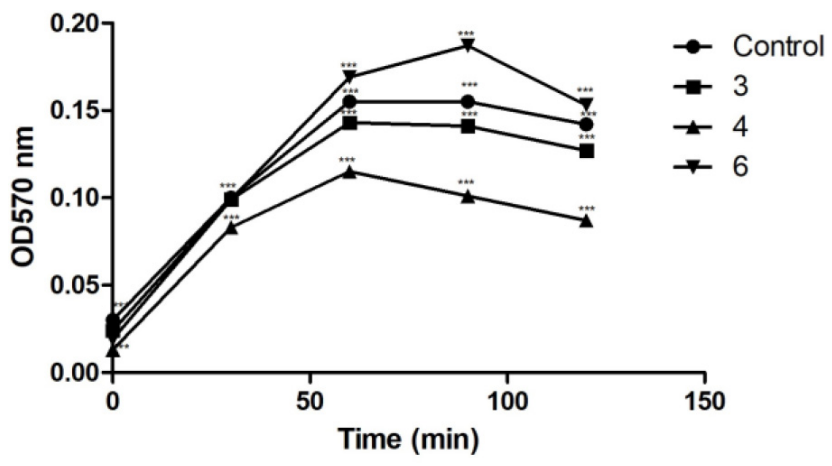

Figure 5: Enzymatic dehydrogenase activity of bacterial cell treated with different compounds $(3,4$, and 6$)$.

(The statistical significance was analyzed by two-way ANOVA test and compared with positive control in every time duration which represent ${ }^{*} p<0.05,{ }^{* *} p<0.01$ and $* * * p<0.001$ with corresponding standard deviation error of mean).

inhibition and concentration of bacterial dehydrogenase compared with good control. Compounds exposure $(25 \mu \mathrm{g} / \mathrm{mL})$ has a rapid onset of bacterial dehydrogenase inhibition and is potent at $60 \mathrm{~min}$ as shown in Figure 5. The results suggested that compounds (3, 4 and 6) exert more bactericidal activity through the breakdown of the external and internal membranes and bacterial mitochondrial dehydrogenase inhibition. 


\section{CONCLUSION}

In summary, an expeditious approach has been developed to provide an easy access to the biologically active novel azepinone and carbazolo fused quinoline4-carboxylic acid (4) and carbazolo condensed diazocino derivative (6) respectively from 3 in high yield and purity. Synthesized compounds showed impressive antibacterial and antifungal activities in in-vitro assay. Molecular docking studies suggested that the synthesized compounds 3, 4 and 6 exhibits good to excellent affinity towards target microbial proteins. In addition, compound 4 also showed marked inhibition of bacterial dehydrogenase enzyme. The antimicrobial activity of synthesized compounds may be attributed to their affinity towards target microbial proteins. Synthesized compounds (3, 4 and 6) hold substantial antibacterial potential and require further exploration to establish them as therapeutic candidates in clinical management.

\section{ACKNOWLEDGEMENT}

The authors are highly thankful to the Vice Chancellor, Prof. Aditya Shastri, Banasthali Vidyapith, Banasthali, India, for providing necessary facilities to carry out present research work.

\section{CONFLICT OF INTEREST}

The authors declare no conflict of interest.

\section{ABBREVIATIONS}

FTIR: Fourier-transform infrared spectroscopy; ${ }^{1}$ HNMR: Proton nuclear magnetic resonance; E. coli: Escherichia coli; B. subtilis: Bacillus subtilis; P. aeruginosa: Pseudomonas aeruginosa; M. phaseolina: Macrophomina phaseolina; F. oxysporum: Fusarium oxysporum; A. Havus: Aspergillus flavus; MTT: 3-(4,5-dimethylthiazol-2-yl)2,5-diphenyltetrazolium bromide; DNA: Deoxyribose nucleic acid; GSK-3: Glycogen synthase kinase 3; $\mathbf{C D C l}_{3}$ : Deuterated chloroform; IR: Infrared spectroscopy; TMS: Tetramethylsilane; PPA: Phenylpropanolamine; TLC: Thin layer chromatography $\mathbf{N a}_{2} \mathbf{C O}_{3}$ : Sodium carbonate; $\mathrm{Na}_{2} \mathrm{SO}_{4}$ : Sodium sulfate; EtOH: Ethanol; AcOH: Acetic acid; $\mathbf{M e O H}$ : Methanol; $\mathbf{H C l}$ Hydrochloric acid; DMF: Dimethylformamide; PDB: Protein data base; TCT: 2, 4, 6-trichloro-1, 3, 5-triazine.

\section{REFERENCES}

1. Vlaar CP, Castillo-Pichardo LC, Medina JI, Marrero-Serra CM, Vélez E, Ramos Z, et al. Design, synthesis and biological evaluation of new carbazole derivatives as anti-cancer and anti-migratory agents. Bioorg Med Chem. 2018;26(4):884-90. doi: 10.1016/j.bmc.2018.01.003, PMID 29358027.

2. Fernandez KMB, Ramos Z, Malave AMF, et al. Synthesis, anti-cancer and anti-migratory evaluation of 3,6-dibromocarbazole and 5-bromoindole derivatives. Molecul. 2019;24(15):1-20.

3. Kaafarani BR, Assaad THE, Smith WA, et al. Bis(tercarbazole) pyrene and tetrahydropyrene derivatives: Photophysical and electrochemical properties, theoretical modeling, and OLEDs. J Mater Chem. 2019;7:5009-18.

4. Salunke JK, Wong FL, Feron K, Manzhos S, Lo MF, Shinde D, et al. Phenothiazine and carbazole substituted pyrene based electroluminescent organic semiconductors for OLED devices. J Mater Chem C;4(5):1009-18. doi: 10.1039/C5TC03690A.

5. Duan H, Li Y, Arora D, Xu D, Lim HY, Wang W. Discovery of a Benzamide Derivative That Protects Pancreatic $\beta$-Cells against Endoplasmic Reticulum Stress. J Med Chem. 2017;60(14):6191-204. doi: 10.1021/acs. jmedchem.7b00435, PMID 28696115.

6. Lassagne F, Duguépéroux C, Roca C, Perez C, Martinez A, Baratte B, et al. From simple quinoxalines to potent oxazolo[5,4-f]quinoxaline inhibitors of glycogen-synthase kinase 3 (GSK3). Org Biomol Chem. 2019;18(1):154-62. doi: 10.1039/c9ob02002k. PMID 31803883.

7. Fluit AC, Schmitz FJ, Verhoef J, Milatovic D. In vitro activity of AZD2563, a novel oxazolidinone, against European Gram-positive cocci. J Antimicrob Chemother. 2002;50(2):271-6. doi: 10.1093/jac/dkf109, PMID 12161411.

8. Orozco D, Kouznetsov VV, Bermúdez A, Vargas Méndez LY, Mendoza Salgado AR, Meléndez Gómez CM. Recent synthetic efforts in the preparation of 2-(3,4)-alkenyl (aryl) quinoline molecules towards anti-kinetoplastid agents. RSC Adv. 2020;10(9):4876-98. doi: 10.1039/C9RA09905K.

9. Edafiogho IO, Phillips OA, Udo EE, Samuel S, Rethish B. Synthesis, antibacterial and anticonvulsant evaluations of some cyclic enaminones. Eur J Med Chem. 2009;44(3):967-75. doi: 10.1016/j.ejmech.2008.07.005, PMID 18715680 .

10. Ali A, Reddy GSK, Cao H, Anjum SG, Nalam MN, Schiffer CA, et al. Discovery of HIV-1 protease inhibitors with picomolar affinities incorporating n-aryloxazolidinone-5-carboxamides as novel P2 ligands. J Med Chem. 2006;49(25):7342-56. doi: 10.1021/jm060666p, PMID 17149864.

11. Gramik VG, Zhidkava AM, Kiselev SS, et al. Synthesis and pharmacological activity of derivatives of quinoline and condensed quinolines. Pharm Chem J. 1978;42(7):881-6.

12. Guda DR, Park SJ, Lee MW, Kim TJ, Lee ME. Synthesis and anti-allergic activity of 2-((bis(trimethylsilyl)methylthio/methylsulfonyl)methyl)-5-aryl1,3,4-oxadiazoles. Eur J Med Chem. 2013;62:84-8. doi: 10.1016/j. ejmech.2012.12.035.

13. Awad IMA, Abdel-rahman AE, Bakhite EA. Synthesis and biological activity of some new heterocyclic quinoline derivatives. Phosphorus Sulfur Silicon Relat Elem. 1991;57(3-4):293-301. doi: 10.1080/10426509108038862.

14. Cabrera LV, Gonzalez E, Rendon A, et al. In-vitro activites of DA-7157 and DA-7218 against Mycobacterium tuberculosis and Nocardia brasiliensis. Am Soc Microgr. 2006;50(9):3170-2.

15. Nazrullaev SS, Bessonova IA, Akhmedkhodzhaeva KS. Estrogenic activity as a function of chemical structure in Haplophyllum quinoline alkaloids. Chem Nat Compd. 2001;37(6):551-5. doi: 10.1023/A:1014873000974.

16. Agrawal M, Jain S, Agarwal A, Dwivedi J, Sharma S, Kishore D. Application of novel precursors derived from carbazolo condensed azepinones to the direct single step synthesis of corresponding isoxazole and pyrazole annulated analogues of medicinal importance. Orient Pharm Exp Med. 2012;12(2):141-50. doi: 10.1007/s13596-012-0060-8.

17. Patel DB, Darji DG, Patel KR, Rajani DP, Rajani SD, Patel HD. Synthesis of novel quinoline-thiosemicarbazide hybrids and evaluation of their biological activities, molecular docking, molecular dynamics, pharmacophore model studies, and ADME-Tox properties. J Heterocyclic Chem. 2020;57(3):1183-200. doi: 10.1002/jhet.3855.

18. Goetz AE, Shah TK, Garg NK. Pyridynes and indolynes as building blocks for functionalized heterocycles and natural products. Chem Commun (Camb). 2015;51(1):34-45. doi: 10.1039/c4cc06445c, PMID 25226878.

19. Agrawal M, Jain S, Sharma S, Dwivedi J, Kishore D. Exceedingly facile onepot protocols to the synthesis of pyrimido annulated analogues of carbazolo condensed azepinones and their evaluation for analgesic activity. Bull Chem Soc Eth. 2017;31(1):93-105. doi: 10.4314/bcse.v31i1.8. 
20. Karki G, Manda PK. Facile synthesis of tetrasaccharide fragments of bioactive Asterosaponins novaeguinosides I and II from starfish Culcita novaeguineae. Arkivoc;2019(5):196-210. doi: 10.24820/ark.5550190.p010.842.

21. Khan KM, Shah Z, Ahmad VU, Khan M, Taha M, Rahim F, et al. Synthesis of 2,4,6-trichlorophenyl hydrazones and their inhibitory potential against glycation of protein. Med Chem. 2011;7(6):572-80. doi: 10.2174/157340611797928415, PMID 22313297.

22. Kunick C, Bleeker C, Prühs C, Totzke F, Schächtele C, Kubbutat MH, et al. Matrix compare analysis discriminates subtle structural differences in a family of novel antiproliferative agents, diaryl-3-hydroxy-2,3,3a,10atetrahydrobenzo[b]cycylopenta[e]azepine-4,10(1H,5H)-diones. Bioorg Med Chem Lett. 2006;16(8):2148-53. doi: 10.1016/j.bmcl.2006.01.071, PMID 16464582.

23. Xie X, Lemcke T, Gussio R, Zaharevitz DW, Leost M, Meijer L, et al. Epoxidecontaining side chains enhance antiproliferative activity of paullones. Eur $\mathrm{J}$ Med Chem. 2005;40(7):655-61. doi: 10.1016/j.ejmech.2005.02.004, PMID 15935900.

24. Saeed S, Rashid N, Jones PG, Ali M, Hussain R. Synthesis, characterization and biological evaluation of some thiourea derivatives bearing benzothiazole moiety as potential antimicrobial and anticancer agents. Eur J Med Chem. 2010;45(4):1323-31. doi: 10.1016/j.ejmech.2009.12.016, PMID 20056520.

25. Available from: http://www.arguslab.com/arguslab.com/ArgusLab.html [cited 29/11/2021].
26. Noha SM, Schmidhammer H, Spetea M. Molecular docking, molecular dynamics, and structure-activity relationship explorations of 14-oxygenated $n$-methylmorphinan-6-ones as potent $\mu$-opioid receptor agonists. ACS Chem Neurosci. 2017;8(6):1327-37. doi: 10.1021/ acschemneuro.6b00460, PMID 28125215.

27. Ukaoma AA, Ukaoma VO, Opara FN, et al. Inhibition of dehydrogenase activity in pathogenic bacteria isolates by aqueous extract of Curcuma longa (turmeric) rhizome. J Phytopharmacol. 2013;2(3):9-17.

28. Tyagi R, Singh B, Kishore D. Synthesis of novel precursors of Pfitzinger reaction: A facile one-pot strategy to the synthesis of quinoline carboxylic acid derivatives of pyrazolo-carbazoles and azacarbazoles. J Chem Sci. 2012;124(2):431-5. doi: 10.1007/s12039-012-0240-6.

29. Musin LI, Bogdanov AV, Mironov VF. Isatin derivatives in reactions with phosphorus (III-V) compounds. Chem Heterocycl Compd (N Y). 2015;51(5):421-39. doi: 10.1007/s10593-015-1717-2, PMID 32214418

30. Deshpande AS, Chamle SN, Yadav MV, et al. Sisal-DCT catalyzed rapid and clean synthesis of bis(indolyl)methanes under mild conditions. Int $\mathrm{J}$ Chem Pharm Rese. 2014;6(7):144-50.

31. Smith KB, Brown MK. Regioselective arylboration of isoprene and its derivatives by Pd/Cu cooperative catalysis. J Am Chem Soc. 2017;139(23):7721-4. doi: 10.1021/jacs.7b04024, PMID 28581713.

32. Weeks RM, Moretti A, Song S, et al. Cationic amphiphiles against Gardnerella vaginalis resistant strains and bacterial vaginosis-associated pathogens. Euro PMC. 2019;77(8):1-44.

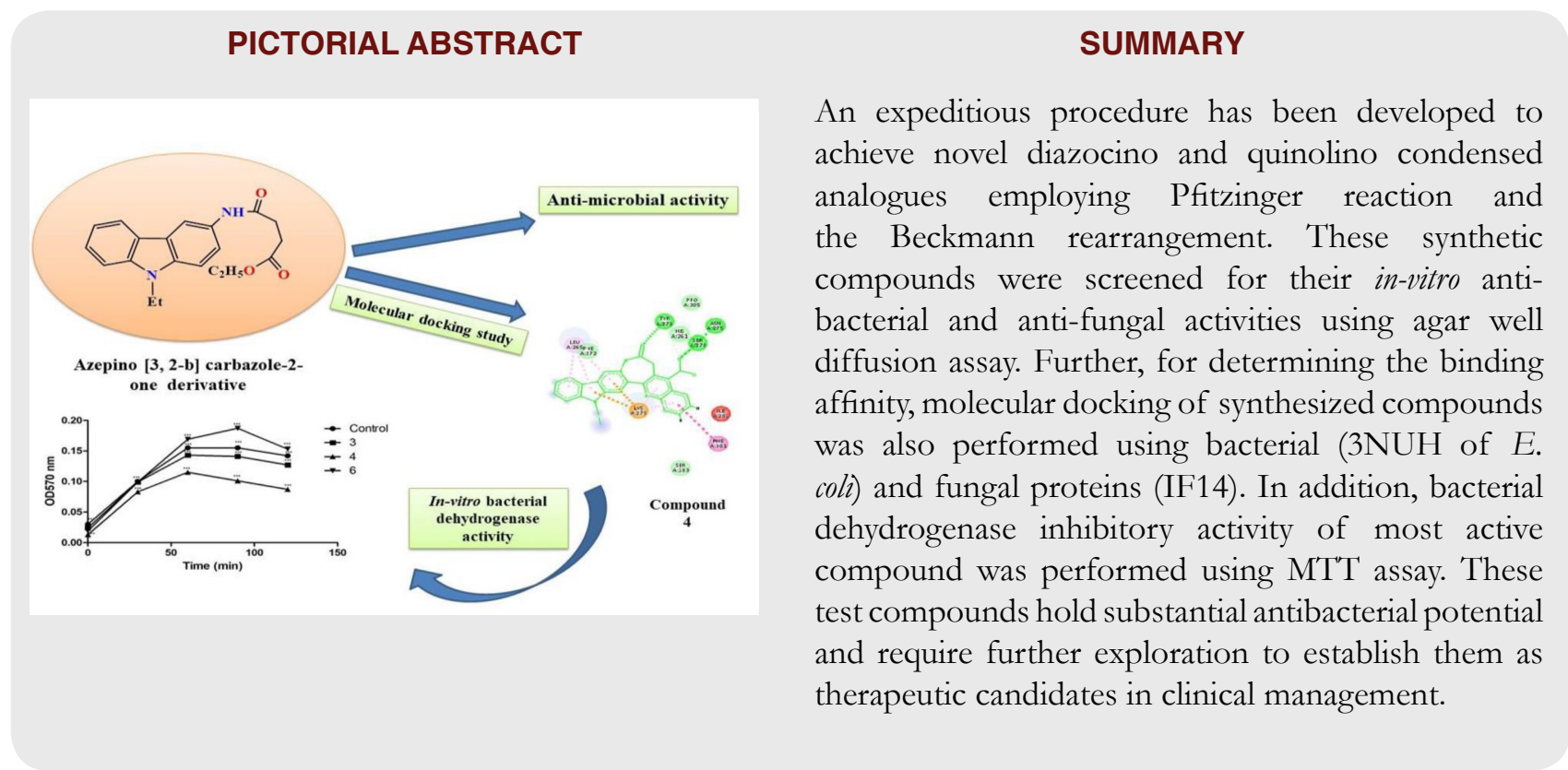

Cite this article: Agrawal M, Dwivedi J, Kishore D, Jain S, Mishra A, Jain S, Sharma S. An Expeditious Approach to the Synthesis of Novel Quinolino and Diazacino Condensed Analogues of Azepino [3, 2-b] Carbazole-2-one of Medicinal Interest. Indian J of Pharmaceutical Education and Research. 2022;56(1s):s89-s97. 